\title{
RANCANG BANGUN SISTEM INFROMASI PENGUKURAN KESEHATAN LAPORAN KEUANGAN PADA PERUSAHAAN JASA (STUDI KASUS PERUSAHAAN JASA YANG TERDAFTAR DI BEI)
}

\author{
Prita Dellia $^{1)}$, Tazul Antoni ${ }^{2)}$, Heni Sulistiani ${ }^{3)}$ \\ 1) Pendidikan Informatika, Universitas Trunojoyo Madura \\ ${ }^{2}$ Sistem Informasi, Universitas Teknokrat Indonesia \\ ${ }^{3)}$ Informatika, Universitas Teknokrat Indonesia \\ Jl. H.ZA Pagaralam, No 9-11, Labuhanratu, Bandarlampung \\ Email :pritadellia@gmail.com ${ }^{1)}$,tazulantoni@gmail.com ${ }^{2)}$,henisulistiani@teknokrat.ac.id ${ }^{3)}$
}

\begin{abstract}
Abstrak
Pertumbuhan ekonomi Indonesia dalam beberapa waktu terakhir masuk ke dalam peringkat ketiga tertinggi di dunia di bawah China dan India. Setiap jenis usaha yang tetap dan terus menerus yang didirikan untuk bekerja dan berdudukan dalam Negara Republik Indonesia ber tujuan memperoleh keuntungan atau laba. Untuk mengetahui keuntungan atau laba setiap perusahaan dibutuhkan laporan keuangan. Penelitian ini bertujuan untuk merancang suatu aplikasi perhitungan laporan keuangan perbankan yang memiliki fitur manajemen user yang dapat menampilkan output berupa laporan keuangan, daftar bank yang digunakan untuk menampilkan hasil perhitungan dan juga dapat menampilkan grafik tingkat kesehatan keuangan berdasarkan perhitungan sebelumnya. Metode yang digunakan dalam pengukuran kinerja laporan keuangan adalah metode RGEC (Risk Profile, Earnings, Capital) yang terdiri dari rasio, \% rasio, peringkat dan kriteria. Dengan bahasa pemrograman PHP, Java Script, HTML dan pengujian sistem menggunakan Black-Box Testing, hasil akhir yang diperoleh dari penelitian ini berupa hasil analisis laporan keuangan dan grafik tingkat kesehatan laporan keuangan perusahaan.
\end{abstract}

Kata kunci: Laporan Keuangan, RGEC, Black-Box Testing

\section{Pendahuluan}

Pertumbuhan ekonomi Indonesia dalam beberapa waktu terakhir masuk dalam peringkat ketiga tertinggi di dunia di bawah China dan India (Nababan, 2016). Meskipun begitu, pertumbuhan ekonomi Indonesia mengalami penurunan dalam setiap tahunnya, terhitung antara tahun 2010 sampai tahun 2015 (Marta, 2017).

Menurut UU No 3 Tahun 1982 “Tentang Wajib Daftar Perusahaan Pasal 1 Huruf B" Dirumuskan bahwa perusahaan ialah setiap bentuk usaha yang menjalankan setiap jenis usaha yang tetap dan terus menerus dan yang didirikan, bekerja serta berdudukan dalam wilayah Negara Republik Indonesia untuk tujuan memperoleh keuntungan dan atau laba. Untuk mengetahui pendapatan atau laba setiap perusahaan dibutuhkan suatu laporan keuangan. Laporan keuangan dibuat untuk mengetahui kondisi keuangan perusahaan tersebut, dan kondisi keuangan suatu perusahaan akan dapat diketahui dari laporan keuangan perusahaan yang bersangkutan, susunan laporan keuangan terdiri dari neraca, laporan rugi laba, laporan perubahan modal dan laporan perubahan posisi keuangan (Munawir, 2010). Laporan keuangan perusahaan dikatakan telah wajar apabila semua komponen dari laporan keuangan telah saling mencocokkan dan secara otomatis laporan posisi keuangan (neraca) harus seimbang dengan berimbangnya bagian debit dengan bagian kredit (Sumarsan, 2013).

Bank merupakan perusahaan yang bergerak dibidang jasa keuangan, bank wajib memelihara dan atau meningkatkan tingkat kesehatan Bank dengan menerapkan prinsip kehati-hatian dan manajemen resiko dalam melaksanakan kegiatan usaha. Kesehatan bank merupakan salah satu hal yang diatur oleh Bank Indonesia. Penilaian kesehatan bank adalah muara akhir atau hasil dari aspek pengaturan dan pengawasan perbankan yang menunjukkan kinerja perbankan nasional.

Banyaknya perusahaan jasa khususnya dibidang Keuangan atau perbankan di Indonesia, diantaranya PT Bank BCA Tbk, PT Bank CIMB Niaga Tbk, PT Bank PAN Indonesia Tbk, PT Bank Maybank Indonesia Tbk dan PT Bank Danamon Indonesia Tbk. Perusahaanperusahaan tersebut merupakan perusahaan keuangan atau perbankan terbesar dan terkemuka di Indonesia dan menjadi perusahaan go public yang telah terdaftar di Bursa Efek Indonesia (BEI), dimana perusahaanperusahaan tersebut juga telah memiliki banyak cabang yang tersebar di hampir seluruh daerah di Indonesia.

Permasalahan yang terjadi dalam beberapa studi kasus tersebut adalah tidak dipublikasikannya tingkat rasio perusahaan perbankan atau jasa sehingga menyulitkan investor dalam memilih jasa perusahaan keuangan atau keuangan dalam berinvestasi. Penelitian serupa pernah diusulkan oleh (Ramadhany dkk, 2015) yang membahas tentang perbandingan tingkat kesehatan Bank berdasarkan Risk Profile, Good Corpoate Governance, Earnings dan Capital (RGEC) pada Bank Konvensional BUMN dan Swasta. Perbedaan tingkat kesehatan Bank berdasarkan RGEC pada perusahaan perbankan besar 
dan kecil juga dapat diijadikan dasar untuk melihat tingkat kesehatan masing-masing bank (Yessi dkk, 2015). Untuk itu, penelitian ini membahas mengenai sebuah rancangan sistem yang mampu mengukur dan menganalisis tingkat rasio keuangan dari beberapa perusahaan jasa keuangan yang terdaftar di BEI.

\section{Pembahasan}

Data yang digunakan dalam penelitian ini adalah data yang diperoleh dari BEI (www.idx.co.id) berupa laporan keuangan audit dari perusahaan jasa keuangan periode 2012 - 2016. Jumlah perusahaan yang menjadi sampel sebanyak lima perusahaan jasa keuangan. Daftar perusahaan yang menjadi sampel dalam penelitian ini dapat dilihat pada tabel 1 .

Tabel 1. Daftar Sampel Perusahaan

\begin{tabular}{|c|l|}
\hline Kode & \multicolumn{1}{|c|}{ Nama Perusahaan } \\
\hline BBCA & PT Bank Central Asia Tbk. \\
\hline BNGA & PT Bank CIMB Niaga Tbk. \\
\hline PNBN & PT Bank Pan Indonesia Tbk. \\
\hline BNII & PT Bank Maybank Indonesia Tbk. \\
\hline BDMN & PT Bank Danamon Indonesia Tbk. \\
\hline
\end{tabular}

Sumber: Bursa Efek Indonesia (www.idx.co.id)

Metode purposive sampling merupakan metode yang dilakukan dengan menenetukan siapa yang termasuk ke dalam anggota sampel penelitiannya dan seorang peneliti harus benar-benar mengetahui bahwa responden yang dipilihnya dapat memberikan informasi yang diinginkan sesuai dengan permasalahan penelitian (Ferdian dkk, 2012). Teknik ini pada dasarnya dilakukan sebagai sebuah teknik yang secara sengaja mengambil sampel tertentu yang telah sesuai dan memenuhi segala persyaratan yang meliputi sifat-sifat, karakteristik, ciri dan kriteria sampel tertentu, dimana dalam hal ini sampel juga harus mewakili populasi. Kriteria sampel yang digunakan dalam penelitian ini adalah:

a. Perusahaan jasa keuangan atau perbankan yang memiliki laporan keuangan periode 2012-2016 dan terdaftar di BEI.

b. Perusahaan jasa keuangan atau perbankan yang secara rutin menerbitkan laporan keuangan.

Metode dan teknik analisa laporan keuangan yang digunakan dalam penelitian ini adalah metode RGEC (Risk Profil, Good Corporate Governance, Earning, and Capital). Penilaian tingkat kesehatan bank yang dilakukan terhadap bank secara individual maupun konsolidasi, terhadap faktor- faktor berikut ini :

a. Penilaian Profil Resiko (Risk Profile)

Merupakan penilaian terhadap resiko inheren dan kualitas penerapan manajemen resiko dalam aktivitas operasioanl bank. Resiko yang wajib dinilai adalah resiko kredit dan resiko likuiditas. Perhitungan yang dilakukan untuk mengetahui resiko kredit dari bank (NPL) menggunakan persamaan (1) dan perhitungan rasio likuiditas untuk pengukuran kemampuan bank dalam memenuhi kewajiban/hutang (LDR) yang harus segera dibayar menggunakan persamaan (2).

$$
\begin{aligned}
& \text { NPL }=\frac{\text { Kredit Bermasalah }}{\text { Total Kredit }} \times 100 \% \\
& \text { LDR }=\frac{\text { Jumlah Kredit yang diberikan }}{\text { Dana Pihak Ketiga }} \times 100 \%
\end{aligned}
$$

b. Penilaian good coorporate governance

Merupakan penilaian terhadap kualitas manajemen bank atas pelaksanaan prinsip- prinsip GCG. Pelaksanaan prinsip- prinsip GCG Bank sebagaimana diatur dalam ketentuan Bank Indonesia mengenai GCG bagi Bank Umum yang dilakukan secara self assessment oleh bank yang besangkutan.

c. Penilaian Rentabilitas (Earnings)

Merupakan evaluasi terhadap kinerja rentabilitas, sumber-sumber rentabilitas, kesinambungan (sustainaibility), rentabilitas, dan manajemen rentabilitas. Rasio yang digunakan untuk menganalisis earnings yaitu Return on Assets (ROA), Return on Equity (ROE) dan Net Interest Margin (NIM).

$$
\mathbf{R O A}=\frac{\text { Laba Sebelum Pajak }}{\text { Rata }- \text { rata total aset }} \times 100 \%
$$

$$
\text { ROE }=\frac{\text { Laba Setelah Pajak }}{\text { Rata }- \text { rata Modal Inti }} \times 100 \%
$$

$$
\text { NIM }=\frac{\text { Pendapatan Bungan Bersih }}{\text { Total Aktiva Produktif }} \times 100 \%
$$

d. Rasio Biaya Rasional Terhadap Pendapatan Operasional (BOPO)

BOPO dihitung untuk mengukur kemampuan manajemen bank dalam mengendalikan biaya operasional terhadap pendapatan operasional.

$$
\text { BOPO }=\frac{\text { Total Beban }}{\text { Total Pendapatan }} \times 100 \%
$$

\section{e. Penilaian Permodalan (Capital)}

Penilaian atas faktor permodalan meliputi evaluasi terhadap kecukupan permodalan dan kecukupan pengelolaan permodalan. CAR dihitung untuk mengukur kemampuan manajemen bank dalam mengelola penyediaan modal minimum.

$$
\text { CAR }=\frac{\text { Total Modal }}{\text { ATMR (Aktiva Terimbang Menurut Resiko }} \times 100 \%
$$

Untuk mengetahui analisis kesimpulannya, masingmasing komponen pada rasio keuangan yang menempati peringkat komposit akan diberikan tolak ukur penilaian sebagai berikut (Refmasari dan Setiawan, 2014).

Peringkat 1 = setiap checklist dikalikan 5

Peringkat $2=$ setiap checklist dikalikan 4 
Peringkat 3 = setiap checklist dikalikan 3

Peringkat $4=$ setiap checklist dikalikan 2

Peringkat $5=$ setiap checklist dikalikan 1

Hasil perkalian dari tiap checklist dibobotkan dengan cara mempersentasekan masing-masing hasil perhitungan komponen. Penentuan terhadap peringkat komposit dari seluruh komponen penilaian digunakan bobot dalam persentase. Tolak Ukur Tingkat Kesehatan Bank dengan Pendekatan Risk-Based Bank Rating (RBBR) dapat dilihat pada tabel 2.

Tabel 2. Tolak Ukur Tingkat Kesehatan Bank

\begin{tabular}{|l|l|}
\hline \multicolumn{1}{|c|}{ Range Nilai } & \multicolumn{1}{c|}{ Keterangan } \\
\hline $86-100$ & PK 1 Sangat Sehat \\
\hline $71-85$ & PK 2 Sehat \\
\hline $61-70$ & PK 3 Cukup Sehat \\
\hline $41-60$ & PK 4 Kurang Sehat \\
\hline$<40$ & PK 5 Tidak Sehat \\
\hline
\end{tabular}

Keterangan: $\mathrm{PK}=$ Peringkat Komposit

\subsection{Analisis Kebutuhan}

Dalam mengembangkan atau membangun suatu sistem informasi publik dilakukan melalui beberapa tahapan diantaranya identifikasi masalah, analisa kebutuhan, mendesain sistem dan maintance sistem (Melinda, Borman \& Susanto, 2017). Untuk mengidentifikasi masalah, harus dilakukan analisis terhadap kinerja, informasi, ekonomi, keamanan aplikasi, efesiensi, dan pelayanan kepada bagian yang terkait (Alfatta, 2007) atau yang dikenal dengan metode PIECES. Dari hasil analisis ini akan diperoleh berbagai usulan untuk membantu sistem yang lebih baik. Sedangkan alat yang digunakan dalam pengembangan sistem dapat dilihat pada tabel 3 .

Tabel 3. Alat Pengembangan Sistem

\begin{tabular}{|c|c|}
\hline $\begin{array}{c}\text { Perangkat Keras } \\
\text { (Hardware })\end{array}$ & Perangkat Lunak (Software) \\
\hline $\begin{array}{l}\text { 1. Processor : Intel } \\
\text { Core i3- } \\
\text { 2. RAM } 4 \text { GB } \\
\text { DDR3L } \\
\text { Memory } \\
\text { 3. Harddisk } \\
\text { 4. Mouse dan } \\
\text { Keyboard }\end{array}$ & $\begin{array}{l}\text { 1. Sistem operasi Windows } 7 \\
\text { 2. Brackets } \\
\text { 3. PHP, Java Script, HTML } \\
\text { 4. Web Browser (Mozila } \\
\text { Firefox, Google Chrome) } \\
\text { 5. MySQL }\end{array}$ \\
\hline
\end{tabular}

\subsection{Analisis Data}

Analisis data adalah langkah yang sangat penting dalam suatu penelitian terutama apabila penelitian tersebut bermaksud untuk mengambil kesimpulan dari masalah yang diteliti. Untuk menganalisis data diperlukan suatu cara atau teknik analisis data. Teknik analisis digunakan untuk menganalisis data hasil penelitian agar dapat diintepretasikan sehingga laporan yang dihasilkan mudah untuk dipahami.
Adapun tahap analisis data yang dilakukan oleh penulis sesuai dengan penelitian sebagai berikut :

a. Melakukan review atas laporan keuangan yang terdiri dari neraca, laba rugi dan catatan atas laporan keuangan.

b. Memasukkan angka rupiah

c. Melakukan interpretasi hasil perhitungan RGEC yang telah dihasilkan oleh 7 variabel (NPL, LDR, ROA, ROE, NIM, CAR, BOPO) untuk menentukan apakah perusahaan tersebut masuk dalam kategori sangat sehat, sehat, cukup sehat, kurang sehat, ataupun tidak sehat.

\subsection{Perancangan Sistem}

Pada penelitian ini menggunakan perancangan sistem Use Case Diagram. Use case dibangun untuk mendeskripsikan sebuah interaksi antara satu aktor atau lebih dengan sistem yang akan dibuat. Rancangan use case dari sistem yang dibangun dapat dilihat pada gambar 1 .

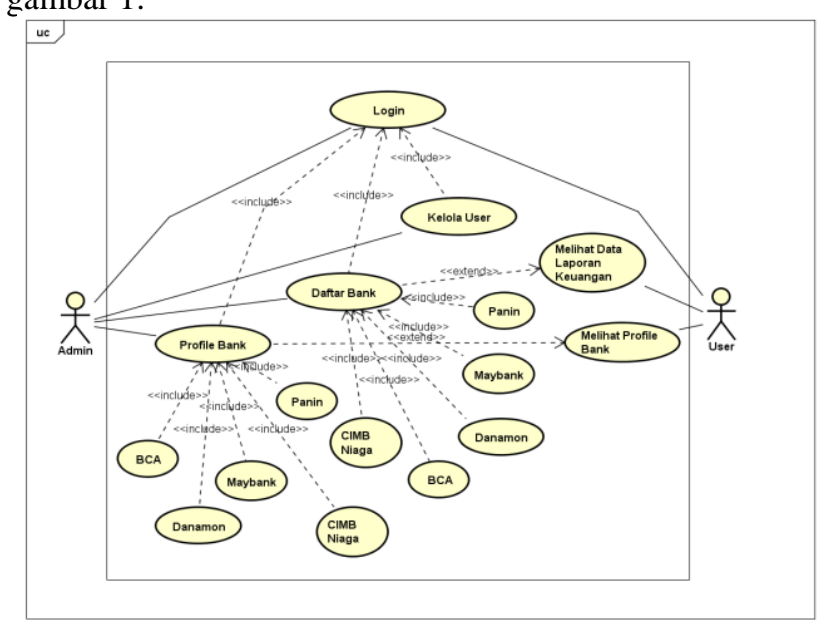

Gambar 1. Rancangan Use Case

Dalam sistem yang dibangun terdapat dua aktor yang terlibat yaitu admin dan user. Admin berwenang untuk melakukan login, manage user, pengaturan akun dan menampilkan data bank menggunakan perhitungan RGEC. Sedangkan user berwenang untuk mengakses menu utama, melihat daftar perusahaan, melihat laporan dan melihat grafik hasil pengukuran kinerja.

\subsection{Implementasi Sistem}

Tahapan implementasi sistem merupakan tahapan kontruksi dengan membuat pengkodean dan mengaplikasikan sistem. Sistem dibangun dengan menggunakan bahasa pemrograman PHP, Java Sccript dan HTML serat database MySQL. Tampilan menu utama dari sistem yang dibangun dapat dilihat pada gambar 2 . 


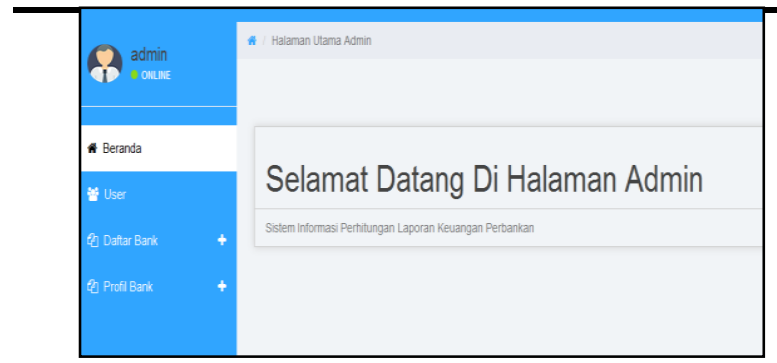

Gambar 2 Tampilan Menu Utama

Dalam sistem ini juga mampu menampilkan daftar Bank yang dijadikan sampel dalam penelitian, dan jika salah satu nama Bank tersebut di klik, mala akam masuk ke halaman hasil perhitungan RGEC dan grafik per tahun. Daftar nama Bank ditampilkan pada gambar 3. Tampilan halaman hasil perhitungan RGEC dan Grafik Pertahun dapat dilihat pada gambar 4 .

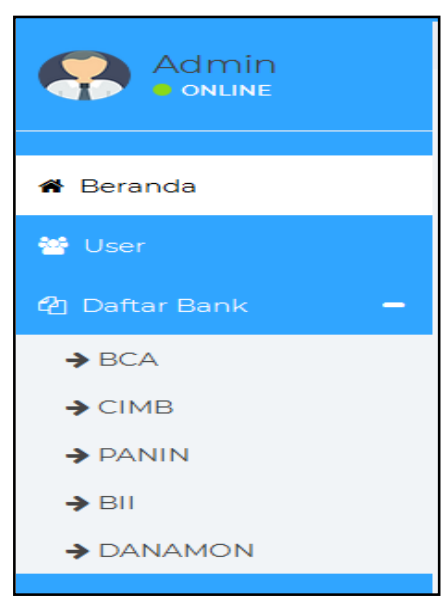

Gambar 3 Tampilan Daftar Nama Bank

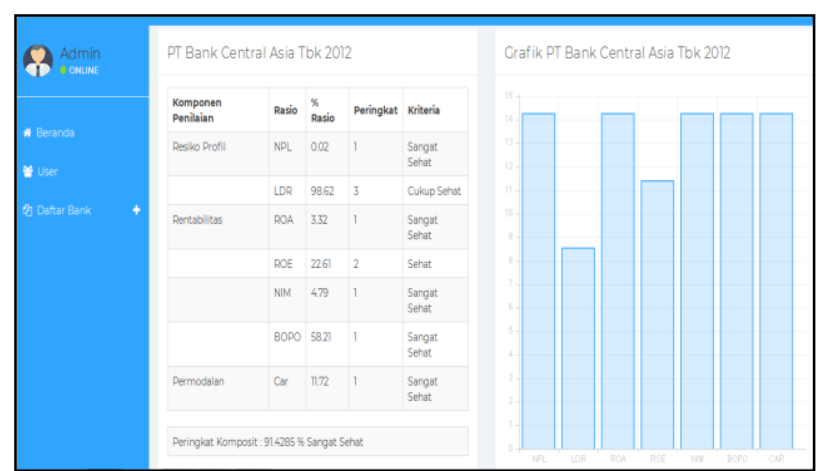

Gambar 4 Tampilan Perhitungan RGEC dan Grafik Pertahun

Sedangkan tampilan grafik seluruh nama bank beserta nilai rasio dapat dilihat pada gambar 5. Dari grafik ini dapat dilihat naik atau turunnya tingkat kesehatan perusahaan dalam kurun waktu lima tahun terakhir.

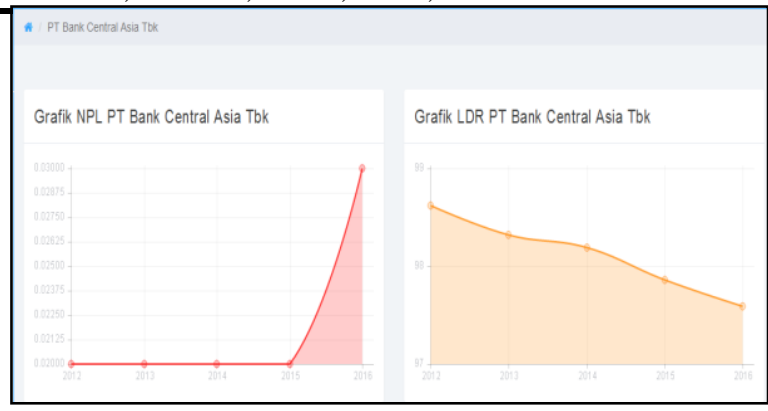

Gambar 5 Grafik Bank Keseluruhan

\subsection{Pengujian Sistem}

Sistem yang telah dibuat selanjutnya dilakukan pengujian, agar sistem yang dibangun sesuai dengan kebutuhan pengguna. Metode pengujian yang digunakan dalam penelitian ini adalah pengujian Black-Box yang dilakukan untuk memastikan bahwa suatu event atau masukan akan menjalankan proses yang tepat dan menghasilkan output sesuai dengan rancangan. Berikut basis implementasi pengujian perangkat lunak sistem informasi pengukur kinerja keuangan menggunakan metode RGEC. Salah satu contoh bentuk pengujian sistem untuk menu daftar bank dapat dilihat pada tabel 4 .

Tabel 4. Pengujian Black-Box Daftar Bank

\begin{tabular}{|c|c|c|c|}
\hline $\begin{array}{c}\text { Data } \\
\text { Masukan }\end{array}$ & $\begin{array}{c}\text { Data } \\
\text { Diharapka } \\
n\end{array}$ & Pengamatan & Kesimpulan \\
\hline $\begin{array}{l}\text { Klik menu } \\
\text { Daftar } \\
\text { Bank }\end{array}$ & $\begin{array}{l}\text { Akan } \\
\text { tampil list } \\
\text { Daftar } \\
\text { Bank yang } \\
\text { tersedia. }\end{array}$ & $\begin{array}{l}\text { Menampilka } \\
\mathrm{n} \text { list Daftar } \\
\text { Bank yang } \\
\text { tersedia }\end{array}$ & $\begin{array}{l}{[\sqrt{ }] \text { Diterim }} \\
\mathrm{a} \\
{[\mathrm{]} \text { Ditolak }}\end{array}$ \\
\hline Pilih Bank & $\begin{array}{l}\text { Akan } \\
\text { tampil } \\
\text { hasil } \\
\text { perhitunga } \\
\text { n RGEC } \\
\text { dan grafik } \\
\text { pertahun. }\end{array}$ & $\begin{array}{l}\text { Menampilka } \\
\mathrm{n} \text { hasil } \\
\text { perhitungan } \\
\text { RGEC dan } \\
\text { grafik } \\
\text { pertahun. }\end{array}$ & $\begin{array}{l}{[\sqrt{ }]} \\
\text { Diterima } \\
{[\quad] \text { Ditolak }}\end{array}$ \\
\hline $\begin{array}{l}\text { Tombol } \\
\text { Lihat } \\
\text { Grafik }\end{array}$ & $\begin{array}{l}\text { Akan } \\
\text { tampil } \\
\text { grafik per } \\
\text { rasio bank. }\end{array}$ & $\begin{array}{l}\text { Menampilka } \\
\mathrm{n} \text { grafik per } \\
\text { rasio bank. }\end{array}$ & $\begin{array}{l}{[\sqrt{ }]} \\
\text { Diterima } \\
{[\text { ] Ditolak }}\end{array}$ \\
\hline $\begin{array}{l}\text { Tombol } \\
\text { Laporan } \\
\text { Keuangan }\end{array}$ & $\begin{array}{l}\text { Akan } \\
\text { tampil } \\
\text { laporan } \\
\text { analisa per } \\
\text { rasio bank. }\end{array}$ & $\begin{array}{l}\text { Menampilka } \\
\mathrm{n} \text { laporan } \\
\text { analisa per } \\
\text { rasio bank. }\end{array}$ & $\begin{array}{l}{[\sqrt{ }]} \\
\text { Diterima } \\
{[\quad] \text { Ditolak }}\end{array}$ \\
\hline
\end{tabular}

Berdasarkan hasil pengujian sistem dengan lima orang user, dapat disimpulkan bahwa sistem yang dibangun tidak tedapat masalah baik dari segi tampilan maupun segi logika pengkodean.

\section{Kesimpulan}

Simpulan yang diperoleh dari hasil pembahasan, yaitu Sistem informasi yang dibangun mampu menampilkan 
daftar bank yang dijadikan sampel dalam penelitian dan mampu menampilkan tingkat kesehatan perusahaan jasa dalam bentuk grafik. Berdasarkan hasil pengujian sistem menggunakan metode Black Box, menunjukkan bahwa sistem yang dibangun tidak memiliki permasalahan yang berarti dan sistem tersebut mampu diterima oleh pengguna baik dari segi tampilan maupun dari segi logika pengkodean yang dibuat.

\section{Daftar Pustaka}

Alfatta, Hanif. 2007. Analisis dan Desain Sistem Informasi Untuk Keunggulan Bersaing Perusahaan dan Organisasi Modern. Graha Ilmu: Yogyakarta

Ferdian, Fajar, Ine Maulina, Rosidah. 2012. Analisis Permintaan Ikan Lele Dumbo (Clarias Gariepinus) Konsumsi di Kecamatan Losarang Kabupaten Indramayu. Jurnal Perikanan dan Kelautan, Vol. 3 No. 4.

Marta, Muhammad Fajar. Saling Salip Bank Papan Atas. Dipetik 17 Oktober 2017, dari kompas.com http://ekonomi.kompas.com/read/2017/03/23/082 400326/saling.salip.bank.papan.atas

Melinda, Mia, Rohmat Indra Borman, Erliyan Redy Susanto. 2017. Rancang Bangun Sistem Informasi Publik Berbasis Web (Studi Kasus: Desa Durian Kecamatan Padang Cermin Kabupaten Pesawaran).

Munawir. 2010. Analisa Laporan Keuangan. Yogyakarta: Penerbit LIBERTY. 2017. Jurnal Tekno Kompak, Vol. 11 No. 1.

Nababan, Christine Novita. (2016, November 13). Jokowi : Pertumbuhan Ekonomi RI Tertinggi Ketiga Dunia https://www.cnnindonesia.com/ekonomi/2016111 3172753-78-172338/jokowi-pertumbuhanekonomi-ri-tertinggi-ketiga-di-dunia/

Ramadhany, Adinda Putri dkk. 2015. Analisis Perbandingan Tingkat Kesehatan Bank Berdasarkan Risk Profile, Good Corporate Governance, Earnings dan Capital (RGEC) Pada Bank Konvensional BUMN dan Swasta. Jurnal Administrasi Bisnis (JAB), Volume 23, Nomor 1.

Refmasari, Veranda Aga dan Setiawan, Ngadirin. 2014. Penilaian Tingkat Kesehatan Bank Umum Menggunakan Metode RGEC Dengan Cakupan Risk Profile, Earnings, dan Capital Pada Bank Pembangunan Daerah Provinsi Daerah Istimewa Yogyakarta Tahun 2012. 2014. Jurnal Profita Universitas Negeri Yogyakarta, 2(1) h:41-54.

Sumarsan, Thomas. 2011. Akuntansi Dasar dan Aplikasi Dalam Bisnis. Jakarta: PT Indeks.

Undang-undang Republik Indonesia Nomor 3 Tahun
1982 Tentang Wajib Daftar Perusahaan.

Yessi. Ni Putu Noviantini Permata dkk. 2015. Analisis Tingkat Kesehatan Bank Dengan Menggunakan Pendekatan RGEC(Risk Profile, Good Corporate Governance, Earnings dan Capital) Pada PT Bank Sinar Harapan Bali, Jurnal Administrasi Bisnis (JAB), Volume 1, Nomor 1. 